\title{
Caustic skin burn caused by sodium hydroxide
}

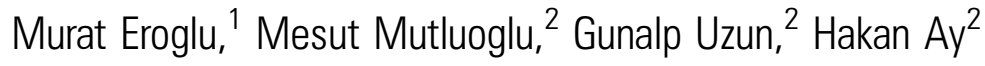 \\ ${ }^{1}$ Department of Emergency Medicine, Gulhane Military Medical Academy Haydarpasa Teaching Hospital, Istanbul, Turkey \\ ${ }^{2}$ Department of Underwater and Hyperbaric Medicine, Gulhane Military Medical Academy Haydarpasa Teaching Hospital, Istanbul, Turkey
}

Correspondence to Dr Mesut Mutluoglu, drmutluoglu@gmail.com

\section{DESCRIPTION}

A 75-year-old, previously healthy, woman presented to the emergency room with bilateral hand wounds. Her medical history revealed the use of a sodium hydroxide $(\mathrm{NaOH})$-impregnated swab without gloves for approximately $2-3 \mathrm{~h}$. Within several hours she felt a burning sensation and noticed significant hyperaemia and blisters over her left interdigitals and her right tenar eminence and fingertips. The next day her complaints aggravated

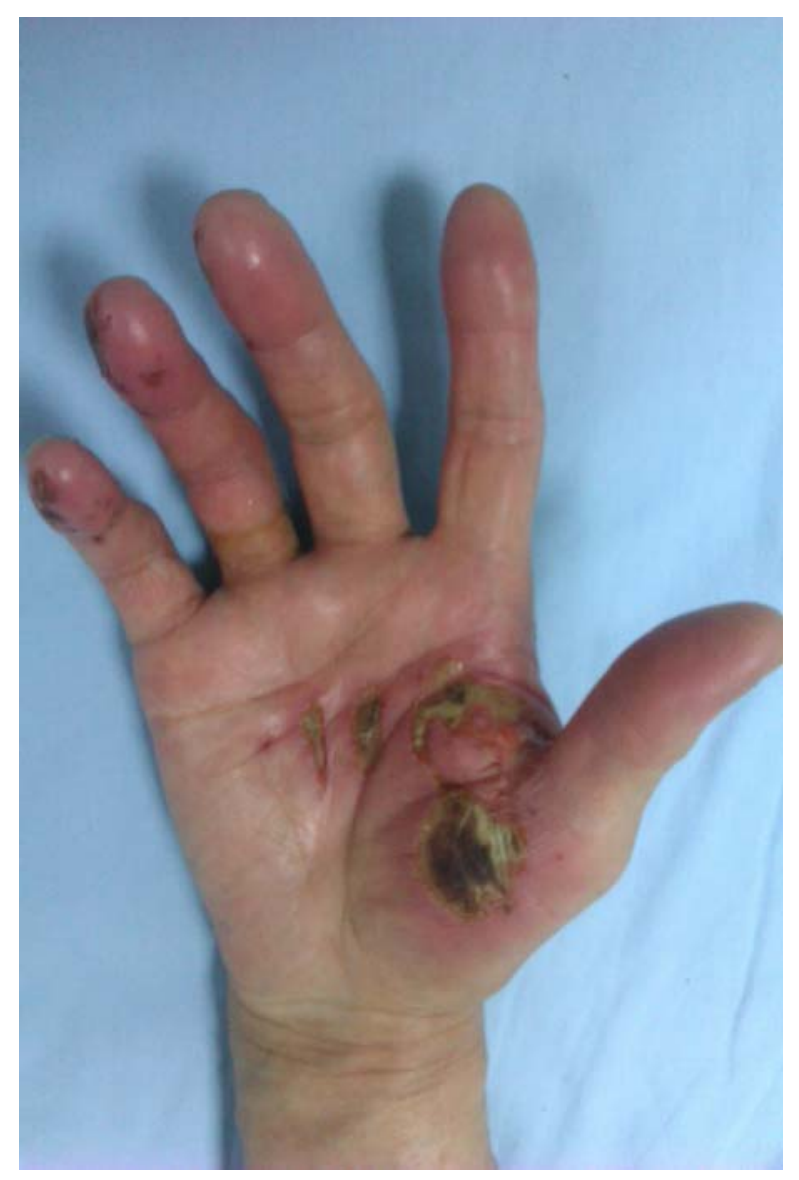

Figure 1 Dry, necrotic, eschar-covered full-thickness ulcer over right tenar eminence. and she developed several wounds over the affected areas. On examination she had a significant dry, necrotic, escharcovered full-thickness ulcer over her right tenar eminence and several other dry necrotic wounds on the described locations (figure 1). Her arterial pulses were palpable and the Doppler ultrasonography examination revealed normal blood flow.

$\mathrm{NaOH}$, often called 'caustic soda', is a strong alkali frequently used in a variety of industries and also in domestic environments as a cleaning agent. Unlike acid burns, which are usually self-limiting and more superficial, caustic soda burns result in deep-liquefactive necrosis and are a cause of significant morbidity due to their late presentation. ${ }^{1}$ Early recognition and prompt management consisting of copious and prolonged wound irrigation is the mainstay of treatment. ${ }^{2}$ Following initial management, these patients usually require a surgical debridement and grafting or conservative wound care until complete epithelialisation. Our patient was lost to follow-up after she was referred to the plastic and reconstructive surgery department. This case illustrates the detrimental effects of $\mathrm{NAOH}$ content cleaning solutions. Extreme care should be taken when handling caustic chemicals, either by wearing protecting gloves or preferably by using less-irritating cleaning agents.

\section{Learning points}

- Extreme care should be used when handling caustic chemicals.

- Immediate medical assistance should be called, in case of any caustic chemical contact.

Competing interests None.

Patient consent Obtained.

\section{REFERENCES}

1. Li YY, Liu Y. Analysis of 155 patients with chemical injury: a 5-year experience. Burns 1993;19:516-18.

2. O'Donoghue JM, Al-Ghazal SK, McCann JJ. Caustic soda burns to the extremities: difficulties in management. Br J Clin Pract 1996;50:108-10. 


\section{BMJ Case Reports}

This pdf has been created automatically from the final edited text and images.

Copyright 2012 BMJ Publishing Group. All rights reserved. For permission to reuse any of this content visit http://group.bmj.com/group/rights-licensing/permissions.

BMJ Case Report Fellows may re-use this article for personal use and teaching without any further permission.

Please cite this article as follows (you will need to access the article online to obtain the date of publication).

Eroglu M, Mutluoglu M, Uzun G, Ay H. Caustic skin burn caused by sodium hydroxide. BMJ Case Reports 2012;10.1136/bcr-2012-007103, Published XXX

Become a Fellow of BMJ Case Reports today and you can:

- Submit as many cases as you like

- Enjoy fast sympathetic peer review and rapid publication of accepted articles

- Access all the published articles

- Re-use any of the published material for personal use and teaching without further permission

For information on Institutional Fellowships contact consortiasales@bmjgroup.com

Visit casereports.bmj.com for more articles like this and to become a Fellow 